\title{
Biological soil crusts as an integral component of desert environments
}

\author{
Jayne Belnap ${ }^{1}$ and Bettina Weber ${ }^{2,3^{*}}$
}

The biology and ecology of biological soil crusts, a soil surface community of mosses, lichens, cyanobacteria, green algae, fungi, and bacteria, have only recently been a topic of research. Most efforts began in the western U.S. (Cameron, Harper, Rushforth, and St. Clair), Australia (Rogers), and Israel (Friedmann, Evenari, and Lange) in the late 1960s and 1970s (e.g., Friedmann et al. 1967; Evenari 1985, reviewed in Harper and Marble 1988). However, these groups worked independently of each other and, in fact, were often not aware of each other's work. In addition, biological soil crust communities were seen as more a novelty than a critical component of dryland ecosystems. Since then, researchers have investigated many different aspects of these communities and have shown that although small to microscopic, biological soil crusts are critical in many ecological processes of deserts. They often cover most of desert soil surfaces and substantially mediate inputs and outputs from desert soils (Belnap et al. 2003). They can be a large source of biodiversity for deserts, as they can contain more species than the surrounding vascular plant community (Rosentreter 1986). These communities are important in reducing soil erosion and increasing soil fertility through the capture of dust and the fixation of atmospheric nitrogen and carbon into forms available to other life forms (Elbert et al. 2012). Because of their many effects on soil characteristics, such as external and internal morphological characteristics, aggregate stability, soil moisture, and permeability, they also affect seed germination and establishment and local hydrological cycles. Covering up to $70 \%$ of the surface area in many arid and semi-arid regions around the world (Belnap and Lange 2003), biological soil crusts are a key component within desert environments.

A recent symposium at the Ecological Society of America in Portland, OR, U.S.A., highlighted how biological soil

\footnotetext{
* Correspondence: b.weber@mpic.de

${ }^{2}$ Department of Biology, Plant Ecology and Systematics, University of

Kaiserslautern, P.O. Box 3049, Kaiserslautern 67653, Germany

${ }^{3}$ Multiphase Chemistry Department, Max Planck Institute for Chemistry,

Hahn-Meitner-Weg 1, Mainz 55128, Germany

Full list of author information is available at the end of the article
}

crust research has changed since the early days: the research community is now much larger, more vibrant, interconnected, and open to exploring the breadth, diversity, and importance of biological soil crusts. Among the papers presented, we feature in this volume a subset representing new and exciting research in this field. The array of papers here includes the evolutionary history of terrestrial cyanobacteria (Beraldi-Campesi 2013), environmental factors controlling microbial contributors and nutrient cycling (Barger et al. 2013; Marusenko et al. 2013; Büdel et al. 2013), and small-scale and landscape-scale perspectives of biological soil crusts (Weber et al. 2013; DettweilerRobinson et al. 2013; Peterson 2013; Root et al. 2013). First we present a paper about Earth's earliest terrestrial ecosystems, dominated by cyanobacteria rather than vascular plants (Beraldi-Campesi 2013: Early life on land and the first terrestrial ecosystems). We next feature two papers that make use of new cutting-edge technologies to study nitrogen dynamics at the micro-scale inside the soil crusts (Barger et al. 2013: Denitrification from nitrogen-fixing biologically crusted soils in a cool desert environment, Southeast Utah, USA; and Marusenko et al. 2013: Ammonia-oxidizing archaea and bacteria are structured by geography in biological soil crusts across North American arid lands). A big question is how these organisms survive under the extreme conditions found in deserts. Our next paper, by Büdel et al. (2013), addresses the different carbon fixation strategies of Sonoran desert biological soil crust types [Lichen species dominance and the resulting photosynthetic behavior of Sonoran Desert soil crust types (Baja California, Mexico)], which adds to our understanding of these survival strategies. Among the most fascinating components of deserts are hypolithic organisms (those living underneath translucent rocks) and how small-scale distribution patterns and microclimatic conditions of these organisms compare to soil-inhabiting crusts. This was investigated by Weber et al. (2013); Ecological characterization of soil-inhabiting and hypolithic soil crusts within the Knersvlakte, South Africa. Few longterm studies on biological crust communities are available, 
and so we present data on long-term changes in a biological crust community from the Columbia Basin, U.S.A., by Dettweiler-Robinson et al. (2013); Long-term changes in biological soil crust cover and composition. Lastly, we present two studies that examine threats to biological soil crusts at the landscape scale. The first paper by Peterson (2013) addresses a critical problem in the western U.S.: how invasive annual grasses and biological soil crusts respond to each other (Regional-scale correspondence among biological soil crusts, invasive annual grasses, and disturbance). The second paper by Root et al. (2013); Wind farm potential is higher in prime habitat for uncommon soil crust lichens discusses how wind farms in the western U.S. may be threatening the more uncommon lichens found in the region.

A great deal remains to be studied about these complex communities. We intend these papers to stimulate further research and discussion on the critical topic of biological soil crusts. Most studies up to now have focused on single roles (e.g., carbon fixation) or single types of biological crust communities. The challenging next step will be investigating the integral roles of biological soil crusts within ecosystems and documenting and quantifying their ecosystem services. This will require concerted and coordinated efforts among different scientific sub-disciplines such as taxonomy, physiology, carbon and nutrient cycling, and hydrology. We need to utilize similar methodologies to address specific questions to allow joint analyses and modeling of the results on larger scales. Of critical importance is gaining an understanding of how the ecological roles of biological soil crusts respond and how the ecosystem services they provide are altered as land use and climate changes around them. To accomplish this vision, we need greater and continued collaboration and networking among scientists, as well as sharing of information with the public and managers. The symposium at ESA and this special volume are examples of ways in which this next stage of research can be accomplished. We look forward to similar efforts in the future, as research continues on this fascinating and critical component of dryland ecosystems.

\section{Competing interests}

The authors declare that they have no competing interests.

\section{Authors' contributions}

$\mathrm{JB}$ and BW designed the manuscript and discussed the different topics, JB wrote the text. Both authors carefully read and approved the final manuscript.

\section{Author details}

${ }^{1}$ U.S. Geological Survey, Southwest Biological Science Center, 2290 S. Resource Blvd, Moab, UT 84532, USA. ²Department of Biology, Plant Ecology and Systematics, University of Kaiserslautern, P.O. Box 3049, Kaiserslautern 67653, Germany. ${ }^{3}$ Multiphase Chemistry Department, Max Planck Institute for Chemistry, Hahn-Meitner-Weg 1, Mainz 55128, Germany.
Received: 1 March 2013 Accepted: 4 April 2013

Published: 16 May 2013

\section{References}

Barger N, Castle SC, Dean GN (2013) Denitrification from nitrogen-fixing biologically crusted soils in a cool desert environment. Southeast Utah, USA, Ecol Proc, 2

Belnap J, Lange OL (2003) Biological Soil Crusts: Structure, Function, and Management. In: Baldwin IT, Caldwell MM, Heldmaier G, Lange OL, Mooney HA, Schulze E-D, Sommer U (eds) Ecological Studies Series 150, vol 150. Springer-Verlag, Berlin, pp 1-503

Belnap J, Hawkes CV, Firestone MK (2003) Boundaries in miniature: two examples from soil. Bioscience 53:739-749

Beraldi-Campesi H (2013) Early life on land and the first terrestrial ecosystems. Ecol Proc 2:1. doi:10.1186/2192-1709-2-1

Büdel B, Vivas M, Lange OL (2013) Lichen species dominance and the resulting photosynthetic behavior of Sonoran Desert soil crust types (Baja California, Mexico). Ecol Proc 2:6. doi:10.1186/2192-1709-2-6

Dettweiler-Robinson E, Ponzetti JM, Bakker JD (2013) Long-term changes in biological soil crust cover and composition. Ecol Proc 2:5. doi:10.1186/21921709-2-5

Elbert W, Weber B, Burrows S, Steinkamp J, Büdel B, Andreae MO, Pöschl U (2012) Impact of cryptogamic covers on the global cycles of carbon and nitrogen. Nat Geosci 5:459-462

Evenari M (1985) The desert environment. In: Evenari M, Noy-Meir I, Goodall DW (eds) Hot deserts and arid shrublands, ecosystems of the world, vol 12A. Elsevier, Amsterdam, pp 1-22

Friedmann I, Lipkin Y, Ocampo-Paus R (1967) Desert algae of the Negev (Israel). Phycologia 6(4):185-195

Harper KT, Marble JR (1988) A role for nonvascular plants in management of arid and semiarid rangelands. In: Tueller PT (ed) Vegetation science applications for rangeland analysis and management. Kluwer, Dordrecht, pp 136-169

Marusenko Y, Bates ST, Anderson I, Johnson SL, Soule T, Garcia-Pichel F (2013) Ammonia oxidizing archaea and bacteria are structured by geography in biological soil crusts across North American arid lands. Ecol Proc 2:9. doi:10.1186/2192-1709-2-9

Peterson EB (2013) Regional-scale relationship among biological soil crusts, invasive annual grasses, and disturbance. Ecol Proc 2:2. doi:10.1186/21921709-2-2

Root HT, McCune M, McCune B (2013) Wind farm potential is higher in prime habitat for uncommon soil crust lichens. Ecol Proc 2:10. doi:10.1186/21921709-2-10

Rosentreter R (1986) Compositional patterns within a rabbitbrush (Chrysothamnus) community of the Idaho Snake River Plain, ProceedingsSymposium on the Biology of Artemisia and Chrysothamnus. USDA Technical Report INT-200. Intermountain Research Station, Ogden, UT

Weber B, Wessels DCJ, Deutschewitz K, Dojani S, Reichenberger H, Büdel B (2013) Ecological characterization of soil-inhabiting and hypolithic soil crusts within the Knersvlakte. South Africa Ecol Proc 2:8. doi:10.1186/2192-1709-2-8

\section{doi:10.1186/2192-1709-2-11}

Cite this article as: Belnap and Weber: Biological soil crusts as an integral component of desert environments. Ecological Processes 2013 $2: 11$.

\section{Submit your manuscript to a SpringerOpen ${ }^{\odot}$ journal and benefit from:}

- Convenient online submission

- Rigorous peer review

- Immediate publication on acceptance

- Open access: articles freely available online

- High visibility within the field

- Retaining the copyright to your article

Submit your next manuscript at $>$ springeropen.com 